\title{
The Role of Lawyer in Establishment of Rule of Law and Protection of Human Rights
}

\author{
Ebad Rouhi*1 \\ Leila Raisi² \\ Mahmoud Jalali ${ }^{3}$ \\ 1 PhD Candidate of Public International Law, Department of Law, Isfahan (Khorasgan) Branch, \\ Islamic Azad University, Isfahan, Iran \\ ${ }^{2}$ Assistant Professor, Law Department, shahrekord Branch, Islamic Azad University, Chaharmahal va Bakhtiari, Iran \\ ${ }^{3}$ Associate Professor, Law Department, University of Isfahan, Isfahan, Iran \\ ${ }^{*}$ Corresponding Author Email: rouhi.iau@hotmail.com
}

\section{Doi:10.5901/mjss.2016.v7n4p}

\begin{abstract}
One of the items of rule of law in any political and legal system is existence of an efficient and independent judicial system. Independence and efficiency in judicial system and hearing process are not realized without counsellorship and the regulatory and supportive role of the lawyer. With consideration of different approaches and viewpoint of rule of law in its formal and substantive aspects, one could observe the significance of position and role of lawyer and advocacy in establishing the rule of law and protection of human rights in any society. In a broad perspective, one could claim that the lawyer could play a significant role in different stages such as establishment of rule of law and its development, drafting of bills and legislations, trial stage and playing regulatory role as well as teaching rules and making them predictable for the citizens. The review of certain concepts such as equality before the law, the supremacy of law, legal certainty, predictability, objectivity of law, and other elements of rule of law manifests the necessity of presence of lawyer and significance of advocacy in realizing such concepts, establishment of rule of law, and protection, education and training of human rights. In regard to the elements and items of rule of law, the present study aims to apply the substantive and formal conceptions of rule of law so as to explain the role and position of lawyer in establishment of rule of law and protection, promotion and development of human rights.
\end{abstract}

Keywords: rule of law, role of lawyer, judicial independence, equality, human rights.

\section{Introduction}

To realize justice and prevent the abuse and violation of rights, the theorists of philosophy of law and political thought refer to the theory of rule of law and believe that through the rule of law, one can witness a dynamic, sustainable and vibrant society in which the law dominates every action, entity and figure. Despite of polemical and controversial nature of the rule of law, all of the associated philosophers and thinkers support this theory and state that this law should dominant every aspects of a society. But each one of them explained the rule of law and offered their distinctive perception of the rule of law based on their ideas and the essence, content and conditions of their surrounding legal and political system. The different conceptions of rule of rule led to different laws and behaviors in every society from the legal, political and judicial viewpoints.

The historical and philosophical evolution of the legal and philosophical thought, as well as international law and the international human rights system shows that the trend toward the rule of law and supremacy of law over structures and figures have an incremental trend and the number of UN General Assembly resolutions on the rule of law manifests the significance of this issue more clearly. Among all conceptions and viewpoints of the rule of law, one could point to two dominant trends each of which promotes a different and significant conception of rule of law and originate the two schools of natural rights and legal positivism. These two dominant conceptions and viewpoints offer distinctive items and elements for the rule of law and refer to different principles of the theory of rule of law. Each one of the two conceptions unexceptionally deal with the role of judicial system and independence of this system in stabilization and application of the rule of law. They regard the rule of law to be impossible without existence of a judicial system. These two conceptions are referred to as the formal and substantive conceptions of rule of law. Different criteria have been developed in regard to the independence of judicial system and its regulative and controlling role in association to the actions of citizens and behavior and decisions of the authorities. The independence of judicial system and its users depends on the competency 
that the system has in realization of justice.

Advocacy as a part of civil society and associated with the judicial system of any society might play a role in different levels to support the rule of law, realize justice and consequently protect and promote human rights. An independent and efficient judicial system as one of the elements of rule of law cannot be realized without advocacy and the supportive and surveillance role of the lawyer. One could clearly observe the significance of position and role of lawyer as well as advocacy in establishment of rule of law and protection of human rights in any society and through the consideration of different viewpoints and conceptions of the rule of law in its formal and substantive kinds.

When lawyers advise clients they help the law to accomplish both its function as a system of social settlement, and the respect for the governed reflected in its processes and structure - i.e., the rule of law. A lawyer can only do so, however, if her advice provides an objectively reasonable assessment of the law, while also facilitating the accomplishment of the client's goals and objectives. (Woolley, 2014:1)

In a broad perspective, one could assert that the lawyer can play a meaningful role in establishment of the rule of law and its promotion, drafting of bills and legislations, trial stage and playing regulatory role as well as teaching rules and making them predictable for the citizens. The review of some items such as equality before the law, the supremacy of law, legal certainty, predictability, objectivity of law, and other elements of rule of law manifests the necessity of presence of lawyer and significance of advocacy in realizing such concepts, establishment of rule of law, and protection, education and training of human rights.

To study the subject and understand the role of lawyer in establishment of the rule of law and protection of human rights, the conception of rule of law as viewed from the advocates of formal and substantive perspective and identification of their elements are reviewed. Then, the position of advocacy and the role of lawyer in realization of elements of rule of law and its effects on support of human rights and reinforcement of models of human rights are studies.

\section{Concept of Rule of Law and Its Different Conceptions}

Rule of law in some form may be traced back to Aristotle, and has been championed by Roman jurists; medieval natural law thinkers; Enlightenment philosophers such as Hobbes, Locke, Rousseau, Montesquieu and the American founders; German philosophers Kant, Hegel, and the nineteenth century advocates of the rechtsstaat; and in this century such ideologically diverse figures as Hayek, Rawls, Scalia, Jiang Zemin and Lee Kuan Yew. (Peerenbom, 2005: 1). Each one of these thinkers has a different approach to the rule of law and its principles and considers different elements for it too. Some believe in formal conception of the theory of rule of law and others believe in a substantive conception of it.

Identifying conditions necessary for a society to be said to be subject to the rule of law does not tell one much about the content of the society's laws, and there is widespread disagreement over exactly what that content must be. Some thinkers in the area focus on the existence of a structure and fair procedures for making and enforcing laws. Others focus more heavily on the content of the law itself. The two concerns are reflected by two views of the rule of law, a formalist one, which emphasizes the procedures for making and enforcing law and the structure of the nation's legal system, or a substantive one, in which certain rights are protected. Using the list of rule of law values described above, the transparency and stability of the law is more closely a formalist concern, while the protection of human rights and fundamental freedoms is a substantive one. While it is important to recognize that legal systems can be described both along formalist and substantive lines, the two are not mutually exclusive (for instance, protection against arbitrary state action). One can be committed to both formalist and substantive requirements for the rule of law. Indeed it is difficult to find someone with a strong substantive approach to rule of law who would not also insist that the state in question follow certain procedures in making and enforcing law. Thus, one set of authors on the subject distinguish between "minimalist" approaches that may be merely formalist and "maximalist" approaches that include both formalist and relatively strong substantive components. (Cole, 2011:9)

The rule of law has been described as a "significantly important concept not defined before and not easily definable". This is due to the diversity of elements and items of this concept which change in regard to different perspectives. The rule of law is a significantly polemical idea for which one cannot find a shared frameworks among the experts that endeavored to define it (Markaz Malmiri, 2007:20). Despite its nearly universal appeal, rule of law, like human rights, is an essentially contested concept. It means different things to different people and has served a wide variety of political agendas from Hayekian libertarianism, to Rawlsian social welfare liberalism, to Lee Kuan Yew's soft authoritarianism, to Jiang Zemin's statist socialism, to a Sharia-based Islamic state. That is both its strength and its weakness. That people of vastly different political persuasions all want to take advantage of the rhetorical power of rule of law keeps it alive in public discourse, but it also leads to the worry that it has become a meaningless slogan devoid of any determinative content. At its most basic, rule of law refers to a system in which law is able to impose meaningful restraints 
on the state and individual members of the ruling elite, as captured in the rhetorically powerful, if overly simplistic, notions of a government of laws, the supremacy of the law and equality of all before the law. (Peerenboom, 2005: 18-19). Different formulations in regard to formal and substantive conceptions of the rule of law could be observed.

Minimum consensus as the condition of acknowledgement of the concept of rule of law can be framed in two propositions. First, the state should make rational decisions and act accordingly. This means that realization of decisions should be based on "reasons". Second, reasons in one of its significance should be legal too. These two abstract propositions are formal ones and as a result, they seem to be sufficiently non-polemical. The first proposition does not presume a certain type of government and does not suggest an objective entity of "state". In the same vein, the second proposition does not include a certain substance or content of "legal reasons" (Tremblay, 1997: 31).

One might regard the most famous and comprehensive written expression of the concept of the rule of law to be the explained concept of Albert Venn Dicey. It seems that from the viewpoint of most of the thinkers of the realm of rule of law, Dicey is regarded as the reformer of "rule of law" (Markaz Malmiri, 2007: 28). Based on the Dicey's viewpoint, one could say that the rule of law is about the supremacy of law to human state and government. In other words, it refers to absolute supremacy law to human. In addition, the equality of all individuals, despite of their political and social position as well as submission to legal authorities, is associated to the principle of rule of law (Rostam Nejad and Rahim Khoi, 2012: 15). In all of the associated theories, one could witness the existence of the concept of equality before the law, submission to law and its supremacy. In this regard, there is almost no difference among them. The differences are realized in content and essence which lead to distinctive perceptions of different elements of this concept.

In formal conception of rule of law, the compliance with the law and application of the principle of "legality" are regarded as the most important principles. However, in substantive conceptions of the rule of law, attention to other extralegal and ethical principles and standards such as principles of natural law and principles of justice are significant and constitute an essential element of the theory of rule of law (Markaz Malmiri, 2007: 56). The first significant point in distinction of these two conceptions is the association of these conceptions with two categories of theories on the association between "legal fact" and "moral fact", namely the theories of "natural right" and theories of "legal positivism". The theories of legal positivism associate "legal argument" with external reality and merely consider something as "law" when it is announced as "law" by competent authorities. But the theories of natural rights regard legal argument as equivalent with moral argument and consider real law to be the one which is compliant with moral law (Rasekh, 2006: 7376). The positivists regard something with legal form, formally passed by competent authorities and going through the procedural process of legalization as law. They regard its realization and implementation as equivalent with rule of law. As a result, they do not concern themselves with just and moral content of law or basing the law on the principles and standards of human rights while naturalists pay more attention to the content of legal system and essence of law. They consider the rule of law to be legitimate and legal when its compliance with fairness, equality, freedom, ethical values and human rights with legislated issue exists.

However, the advocates of both conceptions agree that the objective of rule of law is limitation of state authorities in exercising their powers. Despite of this agreement, each one of these approaches implement different instruments and means to obtain their objective. The formal conception of rule of law lacks verdict in regard to the way of codification of law. In this regard, the significant issue is that the law is passed through competent authorities and satisfies the essential characteristics of law (Rasekh, 2006: 65). From this viewpoint, the necessary and sufficient conditions of regarding a text as law are compliance with characteristics, formal and ritual conditions, as well as approval by a competent authority. Therefore, the implementation of such a bill or act is regarded as the rule of law from the viewpoint of advocates of formal conception. The advocates of substantive conception of rule of law explain the rule of law from a perspective beyond legal positivism and with consideration of other fundamental values. In fact, this conception goes beyond a formal approach and necessitates the law to consider some substantive characteristics. The main characteristic of substantive conception is emphasis upon the dominant role of moral teachings codified in law.

In substantive conception of rule of law, constitutionalism is regarded as a part of theory of rule of law. The rule of law and the constitution have joint objectives the realization of which lead to support of human rights and its reinforcement. The framing and limitation of power, establishment of democratic rule, guaranteeing rights and civil liberties as well as realization of justice are the common objectives of these two concepts. The exercise of freedoms is guaranteed only when they are codified as a set of personal rights in a charter of rights based on the constitution. The defense of rights and liberties is the necessary condition for realization of democracy which is only evaluable through reference of courts to such a charter of rights. This idea had outstanding overlap with the idea of rule of law (Beetham, 2004: 62-63).

Despite of difference in the bases of their viewpoints, the advocates of both conceptions of formal and substantive conceptions follow similar objective in regard to law and its content and utilize their own means and methods so as to limit 
power and options of state authorities, assign supremacy to what they identify as law and dominate it on all state authorities and figures as well as entities of power. Regardless of the content of the law that constitutes the argument between these two approaches, they both agree on the fact that one of the items of rule of law and a condition of its realization is existence of an independent judicial system as a monitoring and controlling authority. Now, this entity that exercises surveillance of state actions and authorities should also follow the law. All of its figures and departments, from judge to officials and other practitioners should obey role. The judicial control as one of the elements of rule of law has established its position in legal-political systems. The effective punishment of official authorities such as suspension, dismissal and obligation to recompense the damages that citizens undertake due to their decision or performance is one of the most significant means of the judiciary to apply the rule of law (Markaz Malmiri, 2007: 186).

The alignment of judicial system with law implies the control of state officials, surveillance over them and realization of rights of citizens and parties of legal cases. The extent of independence of judicial system and its alignment with formal and substantive criteria of rule of law such as Implementation of the law in the same conditions, independence and impartiality, and non-discrimination among the parties of trials represent the extent of realization of rule of law. The judicial independence is an essential and inevitable element of rule of law that plays a fundamental and critical role in application of rule of law. Without the presence of lawyer, consideration of the right to defend, and the role of lawyer as the surveyor and defender, the judicial independence and rule of law cannot be realized. Therefore, one could claim that in this regard, the lawyer has fundamental and undeniable role.

\section{Lawyer and Rule of Law in Courts of Trial}

Every serious thinker about the lawyer's role has recognized the importance of some form of independence of the bar. (Woolley, 2014:3) Equality before the law is one of the intended values by advocates of substantive conception of rule of law and among the intended items of formalist advocates of the rule of law. This concept is one of the primary criteria of fair trial offered in an independent judicial system. Equality is one of the basic values of human rights without which the equality of involved parties in a trial cannot be realized. In such a case, the role of lawyer to establish this concept becomes more significant. The lawyer acts as a surveyor of actions and fair execution of dominant regulations in the trial. $\mathrm{He} / \mathrm{she}$ also plays the role of a defender and evaluator of clarity of judgment process. One of the criteria of fair trial which is itself an element of rule of law is the right to have a lawyer and access to him/her in all stages of trial. Another principle of rule of law and legitimization of legal and political systems is the compliance of legal and political system and system of rule of law with human rights and obligations arising from it. The defensive rights of the defendant are an instance of basic liberties and rights of human which cannot be realized without the presence of lawyer. The violation of defendant's rights is equivalent with violation of human rights, negligence of basic legal rights of a human and violation of one of the components of the rule of law. One could claim that human rights are supported and reinforced by rule of law while they are recognized as an item of rule of law.

UBC law professor Wes Pue argued that "the availability of independent, confidential, and privileged legal advice is essential if law's promise is to be rendered tangible". He suggested that political actors are under "constant" pressure "to undermine the independence of judiciary and lawyer" and that the threat to lawyer independence can arise from overt state action but also through informal activities such as "directions over lunch". Justice Michael Kirby of Australia has similarly argued that accomplishment of the rule of law requires that lawyers be permitted to "advance the interests of their clients fearlessly" without "interference or fear of reprisal". Vancouver lawyer Jack Giles argued that lawyers must be loyal only to their clients, and not to the state. (Woolley, 2014:4) General agreement also exists on the proposition that the destruction of lawyer independence coincides with the undermining of democracy and legality.

The human rights, including procedural and substantive rights, are regarded as the bases of rule of law because one of the primary presuppositions of the theory of rule of law is access of human to rights of moral essence. These are the rights the existence of which is presumed to be based on philosophical-moral arguments. In this regard, the role of the state is merely the identification of existing rights and guaranteeing their consideration. On the other hand, the theory of rule of law seeks to guarantee the rights of citizens through a reliable and stable mechanism. As a result, the rule of law is considered as a guarantee of observation of human rights (Markaz Malmiri, 2007: 92). The mechanisms of supporting the rights of citizens in the courts of trial realized through presence, defense and enlightenments of the lawyer are among such guarantees that deal with support and reinforcement of procedural and substantive rights. The substantive rights are the ones the identification of which is essential for respecting the inherent dignity of human. They are parts of being of human kind just as the right to live and freedom of speech are. But the procedural rights are the ones realized during judgment and emphasize the rights of the accused or the convicted. The procedural rights are actually about substantive rights and guarantee their observation. The lawyer acts as a supervisor and advocate of 
imposition of procedural rights at all stages of the proceedings.

Lawyers who advocate for clients, who construct arguments and help their clients present their perspective in adjudicative proceedings, ensure the accomplishment of the rule of law. So too do lawyers who advise clients about what the law means, and who help those clients to create relationships or undertake endeavors that the law respects or facilitates. Recognition of the rule of law as an unwritten constitutional principle requires us to recognize the constitutional significance of the independence of the bar, of the availability of the advocacy, arguments and advice of counsel. That does not mean that the state may not regulate lawyers. It means only that regulation ought to facilitate and encourage the accomplishment of the lawyer's role in the rule of law, and ought to be viewed with disapprobation when it undermines it. (Woolley, 2014:24)

A fair and public trial, lack of prejudice and bias to correctly execute the law, the ability of the laws to guide the citizens and ease of access to courts are among the principles of natural justice the implementation of which is realized to be consistent with rule of law (Raz, 1977: 201). In association with substantive conception of rule of law, natural justice is one of the primary elements regarding which the lawyer can play a significant role. The important issue in regard to the natural justice and human rights with high significance due to its being the basis of rule of law is the comprehensive association among the concepts of objectivity and the characteristic of generality of law and its impartial measures. The right of defense is based on this general and public principle of criminal law that states: "Nobody should be committed unless he has a reasonable chance to offer his defense and evidence to the court". This principle of natural justice has effective means of guaranteeing the rights and freedoms such as pre-warning the defendant, offering the opportunity to provide comments and reasons, and the principle of obtaining a lawyer. Therefore, the judges 'application of authorities based on exact procedures such as defining sufficient chance to hear the defenses and evidence, collection of sufficient reasons and evidence, and issuing the verdict according to them is among the principles of natural justice (Markaz Malmiri: 2007: 96-97). Without presence of lawyer and his defensive and supervisory role, one cannot properly analyze these measures properly. As a result, the rule of law cannot be effectively realized. The negligence of each one of the above mentioned items is a violation of principles of natural justice as one of the cornerstones of rule of law. Therefore, one can take effective steps through presence of and playing the role by a lawyer.

\subsection{Lawyer and Legal Certainty}

One of the conditions of rule of law is that law should guide its followers. One of the main objectives of rule of law is to play the role of a guideline for the citizens and act as a guide in legal issues. As a result, one could say that natural justice is one of the bases of human rights and the philosophical basis of natural rights which is shared with the concept of rule of law as the citizens' guideline and permissibility of law for guiding its followers. This issue could guide the citizens in a way that they can comprehend the issues and benefit from a legal certainty. The realization of principle of "legal certainty" is one of the main criteria and elements of rule of law which guarantees the application of procedural rights identified and emphasized as natural rights.

Jean-Jacques Rousseau stated: "If the laws of a society are too many for a citizen to remember, those laws are useless because the laws are for the citizens and they lack their function if a citizens does not thoroughly know them" (Roland, 2007: 124). Making the laws understandable by the public in the streets as Rousseau intended can only be fulfilled by the entity of advocacy. The revival and development of these concepts and their public education might be an effective step in this regard. The understanding of rights and laws helps one to be aware of their violations, get dominant over the instruments of defending and dealing with lawlessness and violation of rights and apply them whenever possible. This issue is highly significant in societies with non-democratic structures because it is the most basic impediment against any violations of basic rights.

The advocacy, in addition to direct involvement in trial and what is commonly conceived about lawyer in investigation process, plays an indirect role in the society and social life through explanation of the role of defense, revival, education and development of citizenship rights, publicizing the laws for legal visitors, making legal concepts understandable for the public and attribution of supremacy to law, citizenship rights and principles of human rights in criminal justice systems. The indirect support of the culprit would be effective based on enlightenment and notifications of the lawyers. They can support the public and whoever accused of an offense and prevent the undertaking of losses by somebody due to his ignorance of the laws. The advocacy and the advocate could be effective in the culprits' fate and play a significant role due to their special competencies (Raisi \& Rouhi, 2013: 72). 


\subsection{Lawyer and Measure of Equality in the Rule of Law}

One of the main criteria and elements of rule of law is equality. The principles of equality exist in both types of formal and substantive conceptions of rule of law which constitute one of the cornerstones of rule of law. This means that everybody is equal before the law and the law should be equally applied on all of its followers. In addition, the content of laws should be identical for everybody. Equality before the law originates from formal conception of rule of law in which assigning any special advantage and right to a distinctive individual or group is denied and endeavors to applied law on everybody in an unbiased and impartial manner. One of the objectives of rule of law is to equally implement the laws and realize justice. The realization of justice in any society is due to existence of an independent judicial system to guarantee the fair and impartial implementation of the laws. The objective application of the laws is among the elements of rule of law and at the center of the theory of rule of law. The judicial system, in addition to guaranteeing the supremacy of law and equal application of the rules, should itself include the principles of rule of law. It should do all of its measures in the framework of rule of law and its resulting requirements because the judicial system follows the laws. Otherwise, one cannot expect the rule of law in the society.

One of the basics of fair judgment that is also included among procedural rights is that the involved parties should be in similar conditions of raising the lawsuit, defending and approving it. There should always be a balance between plaintiff and defendant. This finds more significance when the defendant is prosecuted by the court and prosecuting attorney or when a person is questioned intelligence services and power system. In such a case and against its opposing party, plaintiff, prosecuting attorney or intelligence system, should have equal conditions in regard to access to evidence and documents. The equality of means and conditions necessitates that the defendant doesn't undergo unfavorable and feeble conditions in comparison with plaintiff, prosecuting attorney and intelligence system and benefits all of his rights of defense. The advocate might guarantee the defendant's access to these rights, mean and conditions and prevent from deprivation of the defendant from such rights (Rouhi, 2013: 68). So, the advocate can guarantee the equality and observation of procedural rights as instance of human rights and a criterion of rule of law. Lack of culprit's awareness of regulations and rights caused him to be in a feebler condition compared with judicial system or prosecuting attorney as claimant. The presence of lawyer in the process of trial can preserve the rights of the individual or reinforce them. This is among the cases in which the lawyer's role in application of rule of law and support of human right is embodied.

Because the citizens have different conceptions of a good life, if the state prefers one perception to another the state may not act against somebody's offense because of its belief in essential supremacy of him or because the person is supported by numerous powerful groups (Dworkin, 1985: 191). This type of conception might be realized in different social and political layers and cause larger inequalities, even in the judicial system. In sum, the presence of the lawyer can end such inequalities.

\section{Conclusion}

The rule of law had diverse elements which despite of difference in principles and content of formal and substantive conceptions of rule of law, they are generally on the same ground in regard to equality before the law and submission to it, limitation of authorities of state officials and associated entities, independence of judicial system, supremacy of law, division of forces and other similar issues. Each one of these conceptions has different mechanisms to realize the rule of law. In this regard, one of the effective and efficient mechanisms of advocacy is that the advocate executes a part of these mechanisms due to his supervisory and defensive role.

Advocacy, from its formal and substantive aspects, is influential upon application of rule of law and support of human rights. The role of advocate is to ascertain that the equality of plaintiff and defendant is observed, especially when the plaintiff is the public or a governmental entity. In such a case, he might contribute to application of equality as one of the factors of rule of law. The supervisory role of the lawyer can act as a guarantee that the judicial system does not violate the procedural rights and regulations, properly selects and applies the laws, and observes the equality of involved parties in a lawsuit. This role as played by the lawyer can prevent the judicial system to violate impartiality and reinforce its justice and fairness.

One of the elements of rule of law is predictability or certainly of laws. This issue enables the citizens to predict the results of their own actions and get informed of consequences of any action in regard to its legality or illegality. Today, advocacy might play a significant role in publicizing the laws, realizing legal certainty and predictability, and play an educational role as a civil and professional entity. Notification and information by this professional entity could be highly useful and effective in the stage of drafting and codification of rules.

Therefore, one might claim that advocate and advocacy can play a direct role in establishment of rule of law, 
support of human rights and basic freedoms through realization of some elements of rule of law. The denial of lawyer of this role and limiting lawyers to mere presence in trial sessions can act as a major obstacle against the realization of rule of law in any society and would certainly be followed by weakness of civil society and supervisory systems and mechanisms such as the judicial system.

\section{References}

Beetham, D. (2004). Freedom as the foundation. Journal of Democracy. 15 (4), $62-63$.

Cole, M. (2011). Rule of Law Handbook, A Practitioner's Guide for Judge Advocate. The Judge Advocate General's Legal Center and School, U.S. Army \& Center for Law and Military Operations. Charlottesville, Virginia.

Dworkin, R, A. (1995).Matter of principle, Cambridge, Harvard University Press.

Hayek, F, A. (1993). The constitution of liberty, London, Roultledge.

Larkins, Christopher M. (1996). Judicial independence and democratization: A theoretical and conceptual analysis, In Zareii, M, H. (Trans), Aftab Journal, 15.

Markaz Malmiri, A. (2007). Rule of law: Concepts, basics and perceptions, Office of Legal Studies in Research Center of The Islamic Consultative Assembly.

Montesquieu, Ch. (1748). Spirit of laws, Mehtadi, A, A (Trans), Amir Kabir Press, Tehran, Iran.

Peerenboom, R. (2005). Human rights and rule of law: What's the relationship?, Georgetown Journal of International Law. UCLA School of Law Research Paper, 36, 05-31.

Raisi, L\& Rooh, E. (2013). The role of advocate in supporting basic rights of culprit, Bar Association Journal of Isfahan, Iran, No.72 \&73. Rasekh, M. (2006). Theory of right and international human rights, Journal of Legal researches, Tehran University, Iran, 41.

Raz, J. (1977). The rule of law and its virtue. The Law Quarterly Review. 93, 195-211.

Roland, N. (2007), Legal anthropology, In NikPai, a (Trans), Jangal Press, Tehran, Iran.

Roohi, E. (2013). The direct role of advocate in support of culprit's basic rights, Edalat-Gostar Magazine, Payam-e- Noor University Press, Bijar, Iran, No.4. Pp. 60-69.

RosamNejad, H \& Rahim Khoi, E. (2012). Principle of rule of law in international human rights, Kelk-e-Saba Press, Tehran.

Tremblay, L, B. (1997). The Rule of Law, Justice and Interpretation. London, McGill - Queen's University Press.

Woolley, A. (2014). The Lawyer as Advisor and the Practice of the Rule of Law. 47 UBC Law Review. Electronic copy available at: http://ssrn.com/abstract=2450599

Woolley, A. (2014). Lawyers and the Rule of Law: Independence of the bar, the Canadian constitution and the law governing lawyers. 24 National Journal of Constitutional Law, Electronic copy available at: http://ssrn.com/abstract=2435330 